Interdepartmental Scientific-Educational Physicotechnical Center of the Ministry of Education and Science and the National Academy of Sciences of Ukraine, I.I. Mechnikov National University. 2 Dvoryanskaya str. Odessa,65082, Ukraine. e-mail: ndl_lepikh@onu.edu.ua

\title{
A METHOD FOR LOWERING THE LEVEL OF THE ELECTROMAGNETIC WAVES BACKGROUND RADIATION OF HORN RADIATOR
}

\footnotetext{
The problem about decrease in horn radiator electromagnetic waves return radiation level by a method of excitation of the slowed down surface waves on an exterior side of its aperture edge, being in an antiphase with return radiation electromagnetic waves has been solved.

For practical application of this method, a pyramidal H-sector horn radiator with curvilinear walls is taken. In the construction of this method, an impedance metal comb is used, which acts as a delay line for electromagnetic waves reflected from the aperture of the radiator.
}

\section{Introduction}

Horn radiators (HR) refer to an aperture class of the antenna working in a range of ultrahigh frequencies (UHF). Thanks to simplicity of a design and high technical characteristics HR have found wide application in modern radio-electronic communication systems, radar-locations, tele-radio broadcasting, and also in space flying vehicle.

One of HR advantages is the high radiation orientation which is characterised by the orientation diagramme (OD). HR have wide range of working frequencies, high efficiency and possibility to radiate electromagnetic waves of the big capacity (up to $100 \mathrm{MW}$ ) that make them irreplaceable in a radar-location and a space radio communication.

However, there are the various factors worsening HR characteristics. In particular:

1) sphericity of the phase front form in a plane of HR outlet aperture;

2) dispersion of the radiation basic harmonic field energy inside the HR on the set of mode of the higher harmonics;

3) occurrence of the electromagnetic field energy return reflexion in feeding wave guide;

4) occurrence of return radiation into the region of space which is behinde the HR.

The last is caused by a line of the phenomena in which number the most ponderable is the electromagnetic waves reradiation by the currents induced in the HR aperture outlet edge contour (aperture).

The researches [1-9] directed on improvement of HR characteristics have led to occurrence of HR new class with curvilinear walls in which influence of the listed phenomena is considerably reduced. However, the problem of the return radiation remains actual.

In our work the new method of the return radiation level arising on an edge of HR aperture outlet reduction which is applied to pyramidal HR with curvilinear walls is offered.

\section{Problem statement}

Let's consider cross-section of an aperture outlet of pyramidal $\mathrm{HR}$, representing the electric contour of rectangular section $K_{1}$ radiating electromagnetic waves (fig. 1). Sources of an electromagnetic field are alternating currents $i_{1}, i_{2}, i_{3}, i_{4}$. Assume that each site of a contour radiates in space cylindrical waves with a length $\lambda_{0}$ and phase $\varphi_{0}$. Let's by condention, B - the area of direct radiation located in front of HR aperture . The plane of these areas section coincides with a plane of contour $K_{1}$. Let's place the geometrical centre of $K_{1}$ contour at the beginning of the co- 
ordinate system. On an axis $z$ in the region of semispace $A(-z, \pm x, \pm y)$ we will place contour $K_{2}$ identical to contour $K_{1}$ with the geometrical centre with coordinates $(0,0,-l)$.

Then the electromagnetic waves radiated by contour $K_{1}$ having passed distance $l$ during $t_{\text {lag }}$ will induce alternating currents $i_{1}^{\prime}, i_{2}^{\prime}, i_{3}^{\prime}, i_{4}^{\prime}$ in contour $K_{2}$. As the result the system of two radiating contours - active $K_{1}$ and passive $K_{2}$ will turn out, and the phase of radiation of a contour $K_{2}$ $\varphi_{2}$ will lag behind phase $\varphi_{0}$ for time necessary for an electromagnetic wave for overcoming the distance $l$.

At axes $z$ in a distant zone we will pick up the point $M_{z>>\lambda_{0}}$. The distance from zero of coordinate system to point $M_{z>>\lambda_{0}}$ should be 10 times more the wave length $\lambda_{0}$.

The electromagnetic waves radiated by contours $K_{1}$ and $K_{2}$ will reach point $M_{z>>\lambda_{0}}$ not simultaneously, and during $t_{0}=\frac{R_{1}}{c}$ on radiusvector $R_{1}$ and $t_{\text {lag }}=\frac{l}{v}+\frac{R_{2}}{c}$, where $v$ and $c$ electromagnetic waves speed of distribution between contours $K_{1}$ and $K_{2}$, and in free space accordingly. As $R_{1}$ and $R_{2}$ is more than distance between contours $l$ it is possible to consider, that $R_{1}=R_{2}=R$.

It is necessary to define such time of delay $t_{\text {lag }}$ at which in a point of supervision $M_{z>>\lambda_{0}}$ phases $\varphi_{0}$ and $\varphi_{2}$ will differ from each other on size $\pi$.

or

$$
t_{\text {lag }}-t_{0}=\pi
$$

$$
\frac{l}{v}-\frac{l}{c}=\frac{\lambda_{0}}{2 c}
$$

In this case the electric and magnetic field vectors radiated by contours $K_{1}$ and $K_{2}$ are in antiphase for any $x, y,-z 10$ times larger than $\lambda_{0}$ and the resultant capacity stream density in a distant zone of semispace A tends to zero. In semispace $B(z, \pm x, \pm y)$ in a distant zone phases $\varphi_{0}$ and $\varphi_{2}$ will coincide, as the wave passes between contours the distance equal $2 l$ (there and back) for corresponding time $2 t_{\text {lag }}=2 \pi$.

\section{Decision technique}

To fulfill conditions (1-2) it is necessary to reduce the electromagnetic energy distribution speed in the region $z(0,-l)$. For this purpose we will place between conductors of contours $K_{1}$ and $K_{2}$ the slowing down comb type structure made in the form of a flat metal comb (fig. 2).

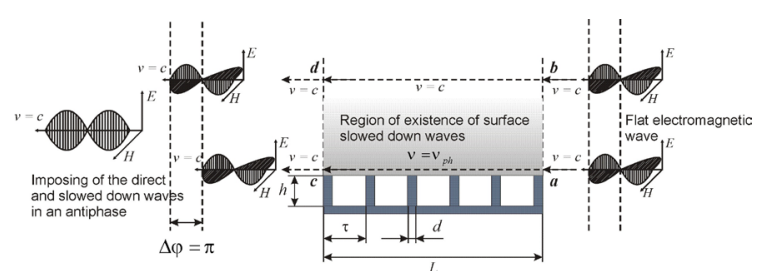

Fig. 2. A fragment of slowing down comb structure on the basis of an impedance metal comb. $\tau$ - the comb period, $I$ - comb length, $d$ - comb thickness, $h$ - comb height, $v$ - slowing down wave speed, $\mathrm{v}_{\mathrm{ph}}$ - phase speed

The first comb (a) corresponds to contour $K_{1}$, the last comb (c) corresponds to contour $K_{2}$.

At interaction of a flat electromagnetic wave with an impedance metal comb over its surface the slowed down surface waves appear. Electrodynamics of the given process is studied enough [10-12]. Having solved the equation (2) concerning speed of the surface slowed down wave $v$ we will receive:

$$
v=c \frac{l}{\frac{\lambda_{0}}{2}+l}
$$


Knowing the $v$ size it is possible to find all geometrical parametres of slowing down structure, namely: $\tau$ - the comb period, $l$ - the comb length,$d$-the comb thickness, $h$ - the comb height at which the condition of formula (1) will be satisfied. Using received in $[2,10,12]$ expressions for slowing down inductive type structure on the basis of an impedance metal comb we will write down the common decision of a problem uniting in geometrical and electrodynamic parametres.

$$
\begin{gathered}
\frac{c}{\sqrt{1+\left(\frac{\tau-d}{\tau} \operatorname{tg} \frac{2 \pi h_{\dot{y}}}{\lambda_{0}}\right)^{2}}}=\frac{l c}{\frac{\lambda_{0}}{2}+l} \\
\left\{\begin{array}{l}
l=6 \div 8 \lambda_{0} \\
\tau<0,5 \lambda_{0} \\
d<<\tau ; \\
0<h_{\text {eff }}<\frac{\lambda_{\max }}{4}
\end{array}\right.
\end{gathered}
$$

where $c$ - speed of electromagnetic waves distribution in vacuum;

$\lambda_{0}$ - length of a wave corresponding to the middle of the operating band;

$\lambda_{\max }$ - maximum length of a wave of the operating band;

$\lambda_{\min }$ - minimum length of a wave of the operating band;

$\tau$ - comb period;

$d$ - comb thickness;

$l$ - comb length;

$h_{\text {eff }}-$ combs effective height counted under the formula:

$$
h_{e f f}=h-0.14(d+\tau)
$$

where $h$ - the constructive (in fact) edge height.

\section{Results and discussion}

For practical application described above method it is taken pyramidal N-sectorial HR with curvilinear walls, in which design the impedance metal comb is included (fig. 3).

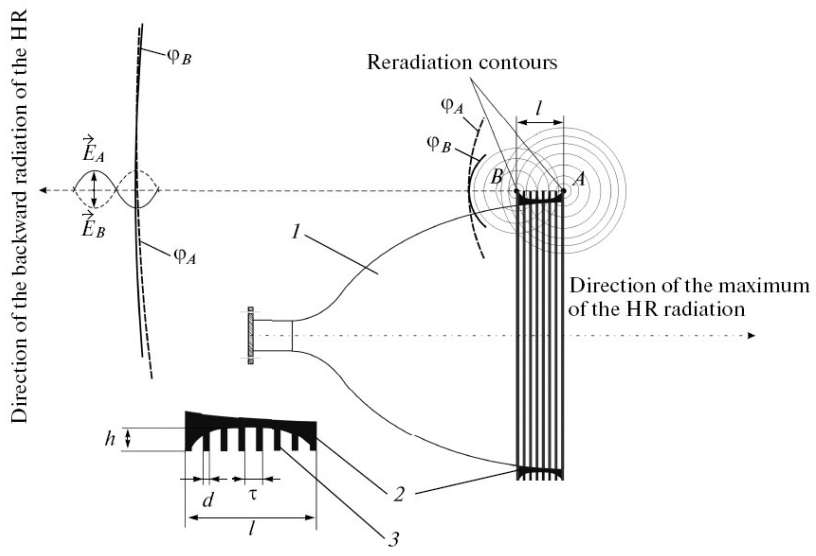

Fig. 3. H-sectorial HR with curvilinear walls of combined form with the return radiation lowered level. 1-H-sectorial HR with curvilinear walls of combined forms, 2- comb type slowing down structure in the form of a flat metal impedance comb in section, 3 - metal comb edge, 1 - metal comb length, $\tau$ - the comb-period, $d$ - comb thickness, $h$ - comb height

The prototype sample of offered HR with following parametres is made and tested:

- the minimum wavelength of the operating

band $\lambda_{\min }=24 \mathrm{~mm}$;

- the maximum wavelength of operating band

$\lambda_{\text {max }}=36 \mathrm{~mm}$;

- the length of a horizontal rib of HR outlet aperture $A_{\mathrm{p}}=100 \mathrm{~mm}$;

- the rib constructive height $h=3 \mathrm{~mm}$;

- the edge thickness $d=0,5 \mathrm{~mm}$;

- the comb period $\tau=5 \mathrm{~mm}$;

-the comb length $l=210 \mathrm{~mm}$;

- Metal comb flutes depth changes on exponential law.

In polar system of coordinates are constructed normalized directional diagrames (DD) of HR prototype sample (solid line) and similar HR, but without impedance comb (dotted line) (fig. 4).

\section{Conclusions}

The analysis of received DD allows to conclude.

1. Level of back lobe DD of HR prototype sample with an impedance comb is considerably less, than at HR without an impedance comb; 
2. At observation angle of $\theta=90^{\circ}$ concerning the radiation maximum in developed HR intensity of an electromagnetic field decreases, and at HR without an impedance comb, on the contrary, in the given point growth of intensity of an electromagnetic field is observed. Theoretical calculations and experimental researches of HR sample confirm efficiency of the offered decision.

\section{References}

1. KarpenkoA.A.Yssledovanyerupornykh yzluchateley po dyapazonnыm svoystvam // Odesa: Haykovi pratsi UDAZ im. O. S. Popova, 2000., №1., S. 76-77.

2. Karpenko A.A., Lepikh Ya.I. Kompensatsyya fazovoy oshybky v yzluchatelyakh SVCh-voln s pomoshch'yu ympedansnoy struktury // Tekhnolohyya y konstruyrovanye $\mathrm{v}$ elektronnoy apparature. 2007., Odesa, №2 (68), S. 38-41.

3. Karpenko A.A., Lepikh Ya.I. Yzluchatel' elektromahnytnykh voln s kombynyrovannoy formoy obrazuyushchykh // Radyotekhnyka i elektronyka. Tom 53., № 7., 2008., Moskva., S. 818-824.

4. Karpenko A.A., Lepikh Ya.I. Metod rascheta rupornoho pyramydal'noho yzluchatelya voln SVCh s kryvolyneynoy obrazuyushchey // Radyoelektronyka. Yzvestyya visshykh uchebnykh zavedenyy KNTU. Tom 51., № 5-6., 2008., Kyev., S. 22-33.

5. Karpenko A.O., Lepikh Ya.I. Vyprominyuvach elektromahnitnykh khvyl' NVCh diapazonu z kerovanym fazovym frontom. Patent na korysnu model' UA № 53694 (51)MPK (2009) H01Q 13/00

6. Karpenko A.O., Lepikh Ya.I. Vyprominyuvach elektromahnitnykh khvyl'. Patent UA №97300 (51)MPK (2012) H01Q 13/02 (2006.01)

7. Karpenko A.O., Lepikh Ya.I. Rupornyy piramidal'nyy vyprominyuvach elektromahnitnykh khvyl' NVCh diapazonu. Patent UA №75105 (51) MPK (2012.01) H01Q 13/00

8. Shumlyanskyy I.I. // Rupornye yzluchately so stupenchatumy y kryvolyneynymy obrazuyushchymy.K.: Vyshcha shk. Holovnoe yzd-vo, 1986. $-147 \mathrm{~s}$.

9. I.I. Shumljansky. Horn radiators of complex configuration. Copyright 1993 by World Scientific Publishing Singapore, New Jersey, London, Hon Kong. Co. Pte. Ltd.

10. Benenson L.S., Kyurkchan A.H. Metod razvyazky antenn pry pomoshchy peryodycheskykh struktur // Radyotekhnyka.- 1995.- № 12.- s. 62-69.

11. Lobkova L.M. Proektyrovanye antenn y ustroystv SVCh: Ucheb. posobye dlya vuzov / L.M. Lobkova. - Sevastopol': Yzd-vo SevNTU, 2002. - $178 \mathrm{~s}$.

12. Habryl'yan D.D., Zvezdyna M.Yu., Kostenko P.Y. Umen'shenye bokovoho y zadneho yzluchenyya antenny na osnove yspol'zovanyya ympedansnykh struktur. // Radyoelektronyka.-2003.№ 2.- . 38 - 43 .

This article has been received in April 2017 


\title{
A METHOD FOR LOWERING THE LEVEL OF THE ELECTROMAGNETIC WAVES BACKGROUND RADIATION OF HORN RADIATOR
}

\begin{abstract}
Summary
The problem about decrease in horn radiator electromagnetic waves return radiation level by a method of excitation of the slowed down surface waves on an exterior side of its aperture edge, being in an antiphase with return radiation electromagnetic waves has been solved.

For practical application of this method, a pyramidal H-sector horn radiator with curvilinear walls is taken. In the construction of this method, an impedance metal comb is used, which acts as a delay line for electromagnetic waves reflected from the aperture of the radiator.

Key words: Horn radiator, horn antenna, surface electromagnetic waves, impedance retardation structure, radiation pattern
\end{abstract}

УДК 621.396 .67

\author{
A. А. Карпенко
}

\section{МЕТОД СНИЖЕНИЯ УРОВНЯ ОБРАТНОГО ИЗЛУЧЕНИЯ ЭЛЕКТРОМАГНИТНЫХ ВОЛН РУПОРНОГО ИЗЛУЧАТЕЛЯ}

\begin{abstract}
Аннотация
Решена задача о снижении уровня обратного излучения электромагнитных волн рупорного излучателя методом возбуждения замедленных поверхностных волн на внешней стороне кромки его раскрыва, находящихся в противофазе с электромагнитными волнами обратного излучения.

Для практического применения данного метода взят пирамидальный Н-секториальный рупорный излучатель с криволинейными стенками, в конструкцию которого включена импедансная металлическая гребёнка, выполняющая роль линии задержки для отраженных от апертуры излучателя электромагнитных волн.
\end{abstract}

Ключевые слова: Рупорный излучатель, рупорная антенна, поверхностные электромагнитные волны, импедансная замедляющая структура, диаграмма направленности. 
A. О. Карпенко

\title{
МЕТОД ЗНИЖЕННЯ РІВНЯ ЗВОРОТНОГО ВИПРОМІНЮВАННЯ РАДІОХВИЛЬ РУПОРНОГО ВИПРОМІНЮВАЧА
}

\begin{abstract}
Аннотація
Розв'язана задача про зниження рівня зворотного випромінювання електромагнітних хвиль рупорного випромінювача шляхом збудження уповільнених поверхневих хвиль на зовнішній стороні кромки його розкриву, що знаходяться в протифазі з електромагнітними хвилями зворотного випромінювання.

Для практичного застосування даного методу взято пірамідальний Н-секторіальний рупорний випромінювач з криволінійними стінками, в конструкцію якого включена імпедансна металева гребінка, що виконує роль лінії затримки для відбитих від апертури випромінювача електромагнітних хвиль.

Ключові слова: Рупорний випромінювач, рупорна антена, поверхневі електромагнітні хвилі, імпедансна уповільнююча структура, діаграма направленості.
\end{abstract}

